\title{
Effects of dietary supplement of methionine and lysine on blood parameters and fur quality in blue fox during low-protein feeding
}

\author{
JOUKO TYÖPPÖNEN ${ }^{1}$, HANS BERG ${ }^{2}$ and MAIJA VALTONEN ${ }^{3}$ \\ I College of Veterinary Medicine, Department of Biochemistry, BOX 6, \\ SF-00551 Helsinki, Finland \\ ${ }^{2}$ Finnish Fur Breeders Association, BOX 92, SF-65101 Vaasa, Finland \\ ${ }^{3}$ Finnish Fur Breeders Association, BOX 5, SF-01601 Vantaa, Finland
}

\begin{abstract}
Four groups of blue fox (Alopex Lagopus) were fed from weaning to pelting with feed of two different protein levels. The metabolizable energy (ME) from protein amounted to $35 / 30 \%$ in the control group and to $22 / 18 \%$ in three low-protein groups during the early and late growth period, respectively. One of the low-protein groups received an unsupplemented diet. The second low-protein diet was fortified with methionine, and the third with methionine and lysine to the same level as in the control diet. Hematological values, urea and creatinine were lower in all low-protein groups as compared to the control group. The activities of amino acid metabolizing enzymes ASAT, ALAT and GGT in plasma were lower in the lowprotein groups although the relative sizes of the liver and kidneys were greater. The lowered protein content in the feed was sufficient for growth, and only a slight negative effect on fur characteristics was observed. The dietary supplementation of methionine and lysine yielded no improvement in the fur quality or other parameters as compared to the unsupplemented low-protein feed, indicating that there was no deficiency of these amino acids in these lowprotein feeds.
\end{abstract}

Index words: methionine, lysine, low-protein feeding, blue fox

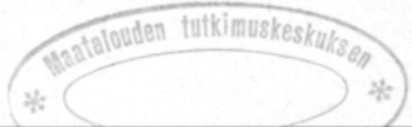

KIRHASTO

\section{Introduction}

In order to produce high-quality furs the feeds for fur-bearing animals contain a relatively high proportion of energy as protein. At the same time, protein is a decisive price factor in feeds. Moderately decreased protein content in mink feed has reduced feeding expenses without affecting the quality of the fur
(Glem-Hansen 1980, Berg et al. 1983, TyöpPÖNEN et al. 1986). Attempts to compensate a markedly lowered protein content in mink feed by the addition of some essential amino acids have not been very successful (MiLovANOV 1963, JørGensen \& GLem-HANSEN 1970, SKrivan 1977, TyöpPönen et al. 1987). The present paper describes an experiment where the possible beneficial effects of supplemental 
methionine and lysine were studied in blue fox fed with diets of low protein content.

\section{Materials and Methods}

\section{Animals and diets}

Four groups of healthy weaned male blue fox (Alopex lagopus) were used in the experiment. The groups consisted of 30 foxes, housed individually in cages. The control group was fed with a diet of standard protein content, i.e. $35 \%$ of metabolizable energy (ME) from protein, from weaning to the end of August and $30 \%$ from September to pelting (Table 1). The three low-protein groups received $22 / 18 \%$ of ME from protein during the early/late growth period. One of the low-protein groups received an un- supplemented diet, the second diet was supplemented with methionine (DL-Methionine, Feed Grade, $98 \%$ ), the third with methionine and lysine (L-Lysine, Monohydrochloride, $98 \%$ ). The levels of methionine and lysine added in the low-protein feeds shown in Table 2 were calculated to be equivalent to the control diet as based on the methionine and lysine content in the raw materials (BERG 1986).

At pelting time, in the beginning of December, blood was collected by cardiac puncture into heparinized tubes, and hematological parameters were determined. For chemical analyses, plasma samples were stored at $-20^{\circ} \mathrm{C}$ until analysed. After blood sampling, the foxes were killed, weighed and the pelt length was measured. The quality and colour of the fur were graded at Finnish Fur Sales Ltd.

Table 1. Composition (\%) of experimental diets during early (I) and late (II) growth period.

\begin{tabular}{|c|c|c|c|c|}
\hline & \multicolumn{2}{|c|}{ Control } & \multicolumn{2}{|c|}{ Low-protein } \\
\hline & I & II & I & II \\
\hline Slaughter offal & 16.0 & 15.0 & 16.0 & 12.0 \\
\hline Cod offal & 14.0 & 13.0 & 6.0 & 5.0 \\
\hline Lessen Sand Eel & 7.0 & 6.0 & 2.0 & 2.0 \\
\hline Herring-fish & 10.0 & 10.0 & 4.0 & 4.0 \\
\hline Fish meal & 3.0 & 5.0 & 2.0 & 2.0 \\
\hline Fish silage & 2.0 & 2.5 & 2.0 & 2.5 \\
\hline Wheat & 6.5 & 8.5 & 8.0 & 11.5 \\
\hline Wheat, precooced & 6.5 & 8.5 & 8.0 & 11.5 \\
\hline Oats bran & 1.0 & 1.2 & 1.0 & 1.2 \\
\hline Fat mixturea & 3.0 & 5.0 & 6.2 & 7.8 \\
\hline Brewer's yeast & 0.5 & - & 1.0 & - \\
\hline Vitamin and mineral mixture & 1.0 & 1.2 & 1.0 & 1.2 \\
\hline Water & 29.5 & 24.1 & 42.8 & 39.3 \\
\hline Dry matter & 31.6 & 37.7 & 32.6 & 38.4 \\
\hline Ash & 2.4 & 2.6 & 1.8 & 1.7 \\
\hline Protein & 11.5 & 12.3 & 8.4 & 8.1 \\
\hline Fat & 6.4 & 8.5 & 8.8 & 10.2 \\
\hline Carbohydrate & 11.3 & 14.3 & 13.6 & 18.5 \\
\hline \multicolumn{5}{|l|}{$\begin{array}{l}\text { Distribution of metabolizable } \\
\text { energy (ME) }\end{array}$} \\
\hline percent from protein & 34.7 & 30.1 & 22.2 & 18.2 \\
\hline percent from fat & 41.7 & 45.2 & 51.6 & 50.8 \\
\hline percent from carbohydrate & 23.7 & 24.7 & 26.2 & 30.9 \\
\hline $\mathrm{ME}, \mathrm{kJ} / \mathrm{kg}$ dry matter & 16740 & 17150 & 18070 & 17900 \\
\hline \multicolumn{5}{|l|}{ Apparently digestible protein } \\
\hline $\mathrm{g} / 100 \mathrm{~kJ}$ & 32.3 & 28.0 & 20.7 & 17.0 \\
\hline
\end{tabular}

a $60 \%$ animal fat, $40 \%$ soybean oil 


\section{Analytical methods}

Hemoglobin $(\mathrm{Hb})$, hematocrit, and leukocyte count were determined by standard methods (Schalm et al. 1975).

Plasma urea was analysed according to Gutmann \& Bergmeyer (1974), creatinine with Jaffe reaction (SьOт 1965), albumin as described by Gindler \& Westgard (1973) and total protein according to WeICHSELBAUM (1946). Aspartate aminotransferase (ASAT), alanine aminotransferase (ALAT) and gamma-glutamyl transferase (GGT) were determined according to the COMMITTEE ON ENZYMES (1974). All the chemical analyses described above were performed with a Gilford System 3500 Computer Directed Analyzer.

Between-group comparison was performed using Student's t-test.

\section{Results and Discussion}

Blood hemoglobin and hematocrit were significantly reduced in fox fed a low-protein feed as compared to the control group (Table 3). Low-protein feeding in mink has resulted in decreased (TYÖPPÖNEN et al. 1986) or unchanged (TYÖPPÖNEN et al. 1987) hema- tological parameters. Leukocyte counts were similar in all groups of blue fox (Table 3).

The content of urea and creatinine in plasma tended to be lower in low-protein groups as compared to the control group (Table 4). The lowered plasma urea concentration reflects the smaller amount of protein available for energy production in these animals. A similar decreasing tendency in plasma urea has previously been observed in mink on lowprotein rations (TYöPPÖNEN et al. 1986, TYöPPÖNEN et al. 1987). Plasma creatinine content correlates with muscle mass of the body. Thus, the slightly lowered creatinine content in low-protein groups probably reflects the slower rate of muscle protein synthesis and turnover as compared to the control group (Table 4).

Albumin and total protein content in plasma were similar in all groups except for the low-protein group supplemented with methionine and lysine where a significant decrease of albumin and an increase of total protein content were observed (Table 4 ). The reason for this phenomenon remained unknown, but increased content of plasma proteins has previously been observed also in

Table 2. Protein levels and amino acid supplements in experimental diets.

\begin{tabular}{|c|c|c|c|c|c|c|}
\hline \multirow[t]{2}{*}{ Group } & \multicolumn{3}{|c|}{ Early growth period } & \multicolumn{3}{|c|}{ Late growth period } \\
\hline & $\begin{array}{l}\text { Protein } \\
(\% \text { ME) }\end{array}$ & $\begin{array}{c}\text { Met } \\
(\mathrm{g} / \mathrm{MJ})\end{array}$ & $\begin{array}{c}\text { Lys } \\
\text { (g/MJ) }\end{array}$ & $\begin{array}{l}\text { Protein } \\
(\% \text { ME) }\end{array}$ & $\begin{array}{c}\text { Met } \\
(\mathrm{g} / \mathrm{MJ})\end{array}$ & $\begin{array}{c}\text { Lys } \\
(\mathrm{g} / \mathrm{MJ})\end{array}$ \\
\hline Control & 35 & & & 30 & & \\
\hline Low-protein & 22 & & & 18 & & \\
\hline Low-prot + Met & 22 & 2.68 & & 18 & 3.35 & \\
\hline Low-prot + Met + Lys & 22 & 2.68 & 7.25 & 18 & 3.35 & 9.38 \\
\hline
\end{tabular}

Table 3. Hematological values and leukocyte count at pelting time (Mean $\pm S D, n=10$ ).

\begin{tabular}{lcccc}
\hline & Control & Low-protein & $\begin{array}{c}\text { Low-protein } \\
\text { +Met }\end{array}$ & $\begin{array}{c}\text { Low-protein } \\
\text { + Met + Lys }\end{array}$ \\
\hline Hemoglobin $(\mathrm{g} / \mathrm{l})$ & $171.4 \pm 6.7$ & $154.6 \pm 15.1^{* *}$ & $163.2 \pm 9.1^{*}$ & $159.6 \pm 7.1^{* *}$ \\
Hematocrit $(\%)$ & $46.9 \pm 2.2$ & $42.9 \pm 5.5^{* *}$ & $46.0 \pm 2.9$ & $44.5 \pm 2.0^{* *}$ \\
Leuk $\left(10^{3} / \mathrm{mm}^{3}\right)$ & $7.6 \pm 3.2$ & $9.2 \pm 5.5$ & $8.5 \pm 3.6$ & $8.6 \pm 2.6$ \\
\hline
\end{tabular}

* $\mathrm{P}<0.05 ; \quad * * \mathrm{P}<0.01$, as compared to control group 
mink during low-protein feeding (TYÖPPÖNEN et al. 1986).

The plasma activities of three enzymes involved in amino acid metabolism (ASAT, ALAT and GGT) are presented in Table 5. The activity of ASAT is high in liver and muscle tissue, but a considerable ASAT activity is also found in other tissues (TYÖPPÖNEN et al. 1982). ALAT is relatively liver specific in blue fox, and GGT activity is strongly concentrated in the kidneys (TYÖPPÖNEN et al. 1982). The activity of amino acid metabolizing enzymes, especially ALAT and GGT, was reduced during low-protein feeding (Table 5). This is probably due to metabolic adaptation to lowered dietary protein content as previously shown to occur in rats (DAS \& WATERLow 1974). Strict carnivores like cat or mink have only a limited ability to this kind of enzymatic adaptation (Rogers et al. 1977,
TYöPPÖNEN et al. 1986). In the present study, the lowered enzyme activities in low-protein groups become even more evident if the increased relative sizes of the liver and kidney are taken into account (Table 6). A similar negative correlation between body weight and liver and kidney weights has previously been observed in Raccoon dog during restricted feeding (Korhonen \& Harri 1985).

The final body weights were similar in all groups (Table 7), but as discussed earlier, the decreased muscle mass, as indicated by the lowered creatinine content in plasma, was probably compensated by the increased amount of body fat. The higher fat and energy contents of the low-protein diets also contribute to such a conclusion (Table 1).

The fur characteristics of the animals are shown in Table 7. There were only slight differences in the presented parameters be-

Table 4. Concentrations of urea, creatinine, albumin and total protein in plasma at pelting time $(M e a n \pm S D, n=10)$.

\begin{tabular}{|c|c|c|c|c|}
\hline & Control & Low-protein & $\begin{array}{c}\text { Low-protein } \\
+ \text { Met }\end{array}$ & $\begin{array}{l}\text { Low-protein } \\
+ \text { Met + Lys }\end{array}$ \\
\hline Urea $(\mathrm{mmol} / \mathrm{l})$ & $4.7 \pm 0.9$ & $3.9 \pm 1.4$ & $3.6 \pm 1.0^{*}$ & $3.7 \pm 1.1^{*}$ \\
\hline Creatinine (umol/l) & $52.2 \pm 6.3$ & $47.4 \pm 6.8$ & $44.9 \pm 9.2$ & $44.8 \pm 7.0^{*}$ \\
\hline Albumin $(\mathrm{g} / \mathrm{l})$ & $37.4 \pm 1.6$ & $36.4 \pm 2.1$ & $35.8 \pm 2.5$ & $35.3 \pm 2.1^{*}$ \\
\hline Total protein $(\mathrm{g} / \mathrm{l})$ & $56.1 \pm 2.8$ & $57.6 \pm 3.0$ & $58.0 \pm 4.3$ & $60.8 \pm 4.1^{* *}$ \\
\hline
\end{tabular}

* $\mathrm{P}<0.05 ; \quad * * \mathrm{P}<0.01$, as compared to control group

Table 5. Activities of ASAT, ALAT and GGT in plasma at pelting time (Mean $\pm \mathrm{SD}, \mathrm{n}=10$ ).

\begin{tabular}{lcccc}
\hline & Control & Low-protein & $\begin{array}{c}\text { Low-protein } \\
+ \text { Met }\end{array}$ & $\begin{array}{c}\text { Low-protein } \\
+ \text { Met }+ \text { Lys }\end{array}$ \\
\hline ASAT (U/1) & $64.6 \pm 29.8$ & $53.8 \pm 22.6$ & $44.0 \pm 12.5$ & $64.0 \pm 22.0$ \\
ALAT (U/1) & $96.6 \pm 42.3$ & $71.0 \pm 29.9$ & $62.6 \pm 19.5^{*}$ & $54.8 \pm 15.6^{*}$ \\
GGT (U/1) & $5.2 \pm 2.3$ & $3.2 \pm 2.2$ & $3.4 \pm 1.9$ & $2.4 \pm 1.8^{* *}$ \\
\hline
\end{tabular}

$* \mathrm{P}<0.05 ; \quad * * \mathrm{P}<0.01$, as compared to control group

Table 6. Organ weights at pelting time (percent of body weight, mean $\pm \mathrm{SD}, \mathrm{n}=10$ ).

\begin{tabular}{|c|c|c|c|c|}
\hline & Control & Low-protein & $\begin{array}{c}\text { Low-protein } \\
+ \text { Met }\end{array}$ & $\begin{array}{l}\text { Low-protein } \\
+ \text { Met + Lys }\end{array}$ \\
\hline Liver & $2.63 \pm 0.18$ & $3.47 \pm 0.29 * * *$ & $3.15 \pm 0.40^{* *}$ & $3.24 \pm 0.54^{* *}$ \\
\hline Kidneys & $0.47 \pm 0.05$ & $0.52 \pm 0.09$ & $0.58 \pm 0.07^{* *}$ & $0.58 \pm 0.16$ \\
\hline
\end{tabular}

** $\mathrm{P}<0.01 ; \quad * * * \mathrm{P}<0.001$, as compared to control group 
tween the groups. Feeding minks with diets similar to those used in the present study led to much more serious consequences in fur characteristics (TYÖPPöNEN et al. 1987). As previously observed in mink, also in the present study the dietary supplements of methionine and lysine had no beneficial effect on fur quality or other parameters as compared to animals fed with low-protein feed without supplemental amino acids.

Acknowledgements. This study was financially supported by the Regional Development Fund of Finland Ltd.

Table 7. Final body weights and fur characteristics (Mean \pm SD).

\begin{tabular}{lcccc}
\hline & Control & Low-protein & $\begin{array}{c}\text { Low-protein } \\
+ \text { Met }\end{array}$ & $\begin{array}{c}\text { Low-protein } \\
+ \text { Met } \\
+ \text { Lys }\end{array}$ \\
\hline $\mathrm{N}$ & 30 & 30 & 27 & 29 \\
Body weight $(\mathrm{kg})$ & $7.53 \pm 1.26$ & $7.85 \pm 1.21$ & $6.98 \pm 1.16$ & $7.31 \pm 1.34$ \\
Pelt length $(\mathrm{cm})$ & $102.0 \pm 4.9$ & $103.0 \pm 4.7$ & $101.4 \pm 4.0$ & $102.1 \pm 4.2$ \\
Fur quality $^{\mathrm{a}}$ & $6.9 \pm 1.8$ & $6.1 \pm 1.4$ & $6.4 \pm 1.4$ & $7.0 \pm 1.0$ \\
Fur covering $^{\mathrm{a}}$ & $6.4 \pm 1.3$ & $6.3 \pm 1.3$ & $5.9 \pm 0.9$ & $6.2 \pm 0.8$ \\
Fur density $^{\mathrm{a}}$ & $7.0 \pm 1.5$ & $6.8 \pm 1.2$ & $6.3 \pm 1.0^{*}$ & $6.7 \pm 1.0$ \\
\hline
\end{tabular}

a $10=$ best $; 0=$ poorest

$* \mathrm{P}<0.05$, as compared to control group

\section{References}

ANON. 1984. COMMITTEE ON ENZYMES OF THE SCANDINAVIAN SOCIETY FOR CLINICAL CHEMISTRY AND CLINICAL PHYSIOLOGY. 1974. Scand. J. Clin. Lab. Invest. 33: 287-306.

BERG, H. 1986. Rehutietoutta turkiseläinkasvattajille (Breeders Handbook for Fur Animal Feeding). The Finnish Fur Breeders Association, Vantaa, Finland, $99 \mathrm{pp}$.

Berg, H., Valtonen, M., Táng, L. \& Eriksson, L. 1984. Protein digestibility and water and nitrogen balance studies with mink at different protein levels. 3e Congr. Int. Sci. Prod. Anim. Fourrure. Versailles, France.

DAs, T.K. \& WATERlow, J.C. 1974. The rate of adaptation of urea cycle enzymes, aminotransferases and glutamic dehydrogense to changes in dietary protein intake. Br. J. Nutr. 32: 353-373.

Gindler, E.M. \& Westgard, J.O. 1973. Automated and manual determinations of albumin with bromcresol green and a new ionic surfactant. Clin. Chem. 19: 647 .

Glem-Hansen, N. 1980. The protein requirements of mink during the growth period. II. Effect of protein intake on growth rate and pelt characteristics. Acta Agric. Scand. 30: 345-348.

Gutman, I. \& Bergmeyer, H.U. 1974. Urea. In Methods of Enzymatic Analysis. ed. 2 (Ed. H.U. Bergmeyer). Academic Press, New York and London, p. 1791.

Jørgensen, G. \& Glem-Hansen, N. 1970. Forsøg med forskellig proteinkoncentration kombineret med til- sătning af methionin. Bilag til forsøgs laboratoriets årsmøde København, 16 pp.

Korhonen, H. \& HaRRI, M. 1985. Organ scaling in the raccoon dog, nyctereutes procyonoides gray 1834 , as monitored by influences of internal and external factors. Comp. Biochem. Physiol. 82A: 907-914.

Mılovanov, L.V. 1963. Importance of amino acids in rations for young mink. Krolik. Zver. no. 9, 18-20 (Nutr. Abstr. \& Rev. 34, no 3375).

Rogers, Q.R., Morris, J.G. \& FreedLAND, R.A. Lack of hepatic enzymatic adaptation to low and high levels of dietary protein in the adult cat. Enzyme 22: 348-356.

Schalm, O.W., Jain, N.C. \& Carrol, E.J. 1975. Veterinary Hematology, ed. 3. p. 807. Lea \& Febiger, Philadelphia.

SKrIVAN, M. 1977. L-lysine, DL-methionine and DLtryptophan in the diet of young and adult visons. Biol. Chem. Vyzivy Zvirat 3: 213-219.

SŁot, C. 1965. Plasma creatinine determination. A new and specific Jaffe reaction method. Scand. J. Clin. Lab. Invest. 17: $381-387$.

Tyóppónen, J., Juokslahti, T. \& Lindberg, P. 1982. Activites of some enzymes in the tissues of the blue fox (Alopex lagopus). Res. Vet. Sci. 33: 295-297.

Työpoónen, J., Valtonen, M. \& Berg, H. 1986. Lowprotein feeding in mink: Effects on plasma free amino acids, clinical blood parameters, and fur quality. Acta Agric. Scand. 36: 421-428. 
TYopponen, J., Berg, H. \& VAltonen, M. 1987. Effects of dietary supplement of methionine and lysine on blood parameters and fur quality in mink fed with low-protein diets. Acta Agric. Scand. (in press).

Weichselbaum, T.E. 1946. An accurate and rapid meth- od for the determination of proteins in small amounts of blood serum and plasma. Amer. J. clin. Pathol. 16: $40-49$.

Ms received May 25, 1987

\section{SELOSTUS}

\section{Ruokinnallisen metioniini- ja lysiinilisän vaikutus sinikettujen veriarvoihin ja nahkalaatuun rehun proteiinipitoisuuden ollessa alhainen}

Jouko Työppönen ${ }^{1}$, Hans Berg ${ }^{2}$ ja Maija Valtonen ${ }^{3}$

' Eläinläaketieteellinen korkeakoulu, biokemian laitos, PL 6, 00551 Helsinki

2 Suomen Turkiseläinten Kasvattajain Liitto, PL 92, 65101 Vaasa

3 Suomen Turkiseläinten Kasvattajain Liitto, PL 5, 01601 Vantaa

Sinikettuja (Alopex lagopus) ruokittiin vieroituksesta nahoitukseen kahdella eri rehulla, jotka poikkesivat toisistaan proteiinitasojen suhteen. Kontrolliryhmän rehun proteiiniperäinen muuntokelpoinen energia (ME) oli $35 \%$ kesäruokintakautena ja $30 \%$ syysruokintakautena. Kolmen koeryhmän rehun vastaavat ME-arvot olivat $22 \%$ ja $18 \%$. Yksi koeryhmistä sai mainittua rehua sellaisenaan, toisen koeryhmän rehuun lisăttiin metioniinia ja kolmannen koeryhmän rehuun sekă metioniinia ettă lysiiniä. Metioniini- ja lysiinilisän määrä vastasi kontrollirehun vastaavia pitoisuuksia.

Hematologiset arvot sekä plasman urea- ja kreatiniinipitoisuudet olivat koeryhmissä alhaisemmat verrattuna kontrolliryhmaaản. Plasmasta mitattujen maksassa ja munuaisissa aminohappoaineenvaihduntaa katalysoivien entsyymien aktiivisuudet ASAT, ALAT ja GGT olivat koeryhmissä alhaisemmat, vaikka maksan ja munuaisten koko năissă ryhmissă oli suurempi verrattuna kontrolliryhmaaăn.

Koeryhmissä käytetty rehun proteiinimäärä oli riittävả kettujen normaalille kasvulle, mutta näiden elăinten nahkatulos oli lievästi heikompi verrattuna kontrolliryhmäăn. Koeryhmien metioniini- ja lysiinilisăt eivăt parantaneet näiden elāinten nahkalaatua tai muita mitattuja suureita verrattuna eläimiin, jotka saivat koerehua ilman năitä lisiä. Tulosten mukaan koerehun syötōstă aiheutuneet muutokset eläimissă verrattuna kontrollieläimiin eivăt aiheutuneet koerehun metioniinin tai lysiinin puutteesta. 